\title{
PREFERENSI PETANI TERHADAP 15 GALUR PADI GOGO DI TABALONG-KALIMANTAN SELATAN
}

\section{FARMER'S PREFERENCE OF 15 UPLAND RICE LINE IN TABALONG-SOUTH KALIMANTAN}

\author{
Ambar Yuswi Perdani ${ }^{*}$, Enung Sri Mulyaningsih ${ }^{1}$, Yuli Sulistyowati', Suherman ${ }^{2}$, \\ Irwan Sanjaya ${ }^{3}$, Muhammad Prastiyo ${ }^{3}$ \\ ${ }^{1}$ Pusat Penelitian Bioteknologi LIPI \\ Jl. Raya Bogor KM 46, Cibinong, Indonesia \\ ${ }^{2}$ Dinas Tanaman Pangan, Hortikultura dan Perkebunan, Kabupaten Bogor \\ Jl. Letjen Ibrahim Adjie, Sindangbarang, Bogor Barat, Jawa Barat, Indonesia \\ ${ }^{3}$ Balai Penyuluhan Pertanian, Bintang Ara \\ Desa Bintang Ara, Kabupaten Tabalong, Kalimantan Selatan, Indonesia \\ Email:amba004@lipi.go.id
}

\begin{abstract}
The production of new varieties of rice must involve farmers as users. Farmers'views of a variety in each region differ depending on consumption patterns, culture and environment. The aims of this research is to determine farmers ' preferences for 15 upland rice lines that were indicated to aluminum tolerant. Data collection is done at Desa Bintang Ara, Kecamatan Bintang Ara, Kabupaten Tabalong, Kalimantan Selatan. A total of 30 farmer respondents assessed the appearance of rice lines at harvest. Observations were made visually of agronomic characters. 15 line of upland rice were planted in a $1 \times 5 \mathrm{~m}$ plot with a spacing of $20 \times 20 \mathrm{~cm}$ without experimental design. During the planting process there are some obstacles such us low soil fertility and plant diseases. The results of the Bintang Ara farmer's assessment preferences were selected for 5 upland rice lines: 1, 2, 4, 22, and 23. Some of the characters chosen were: high plant, width angle of the flag leaf, long panicle, medium plant age, many number of productive tillers, the grain is easy to fall, slim grain, golden yellow grain color, and the aromatic rice.
\end{abstract}

Keywords: Farmers'preferences, lines, upland rice

\begin{abstract}
ABSTRAK
Upaya menghasilkan suatu varietas unggul baru tanaman padi, sudah selayaknya melibatkan calon pengguna seperti petani. Selera petani atau masyarakat di setiap daerah terhadap suatu varietas dapat berbeda bergantung pada pola konsumsi, budaya dan lingkungan setempat. Penelitian ini bertujuan untuk mengetahui preferensi petani terhadap 15 galur harapan padi gogo toleran aluminium. Pengumpulan data dilakukan di Desa Bintang Ara, Kecamatan Bintang Ara, Kabupaten Tabalong, Kalimantan Selatan. Sebanyak 30 responden petani menilai penampilan galur padi gogo pada fase menjelang panen. Pengamatan dilakukan secara visual terhadap karakter agronomis yang tampak. Sejumlah 15 galur harapan padi gogo ditanam pada petak berukuran $1 \mathrm{~m}$ x $5 \mathrm{~m}$ dengan jarak tanam $20 \mathrm{~cm} \times 20 \mathrm{~cm}$ tanpa rancangan percobaan. Selama proses penanaman terdapat sejumlah kendala
\end{abstract}


antara lain tingkat kesuburan tanah rendah dan serangan hama penyakit tanaman. Namun kendala ini tidak mengganggu produksi dan pengamatan. Hasil penjajakan preferensi petani Bintang Ara terpilih 5 nomor galur harapan padi gogo yaitu: 1, 2, 4, 22, dan 23, Galur-galur tersebut dipilih karena memiliki karakteristik sesuai keinginan calon pengguna. Beberapa karakter utama yang dipilih antara lain: tanaman tinggi, sudut daun bendera lebar, malai panjang, umur tanaman dengan kategori sedang. Sementara karakter unggul lainnya yang disukai ialah jumlah anakan produktif banyak, padi mudah rontok, bulir ramping, warna gabah kuning emas, dan aroma beras wangi.

Kata kunci: Galur, padi gogo, preferensi petani

\section{PNDAHULUAN}

Program peningkatan produktivitas padi melalui intensifikasi dan ekstensifikasi terus dilakukan. Intensifikasi tanaman padi dengan perakitan varietas unggul baru berdaya hasil tinggi dan adaptif lingkungan menjadi prioritas. Perluasan areal tanam padi melalui pemanfaatan lahan kering menjadi pilihan bijaksana yang harus dijalankan. Namun sejumlah permasalahan sering kali muncul dalam sistem pertanian padi di lahan kering. Tanah lahan kering pada umumnya merupakan tanah masam suboptimal yang memiliki $\mathrm{pH}$ rendah, kelarutan $\mathrm{Al}^{3+}$ yang tinggi, defisiensi $\mathrm{P}$ karena terfiksasi Al serta mudah terdegradasi karena kation atau mineral di dalam tanah tercuci yang antara lain disebabkan oleh kapasitas tukar kation (KTK) tanah rendah relatif kurang subur karena pencucian hara yang intensif (Iqbal 2012; Matsumoto et al. 2017; Subagyo et al. 2000). Selain itu pada pertanaman padi gogo di lahan kering perlu dicermati dan diantisipasi adanya serangan penyakit blas (Hafif, 2016).

Pemanfaatan lahan kering dengan kategori sub optimal pada dasarnya masih dapat diupayakan menjadi lahan pertanian produktif melalui beberapa pendekatan. Pendekatan pertama ialah mengubah lahan dengan menambahkan banyak bahan ke dalam lahan, pendekatan seperti ini memerlukan input yang besar. Pendekatan kedua ialah dengan meminimumkan input, yaitu dengan menggunakan galur atau varietas yang tahan atau toleran terhadap kondisi cekaman di lokasi. Untuk menghasilkan suatu varietas yang toleran/ tahan perlu dilakukan perakitan tanaman yang sesuai kondisi lingkungan. Dengan pendekatan ini, diharapkan varietas/galur unggul baru dapatberadaptasi baik pada lingkungan tercekam sehingga tetap mampu berproduksi tinggi.

Berdasarkan Mulyani dan Sarwani (2013) luas lahan bercekaman (sub optimal) di Indonesia mencapai 157,2 juta ha. Dari luas tersebut, 108,8 ha diantaranya adalah lahan kering masam. Lahan sub optimal di Indonesia berupa lahan kering: ultisol dan oxisol dan lahan basah seperti: gambut, lahan masan, rawa pasang surut (Yuwono, 2009). Lahan kering masam adalah lahan dengan $\mathrm{pH}<5$, kejenuhan basa $<50 \%$, kadar aluminium tinggi, tekstur tanah klei, dan regim kelembaban tanah udik atau curah hujan $>2.000 \mathrm{~mm}$ per tahun (Subagyo et al., 2000). Secara umum lahan kering masam ini mempunyai tingkat kesuburan dan produktivitas lahan rendah yang disebabkan oleh 
rendahnya kandungan bahan organik, hara, dan toksisitas aluminium (Mulyani dan Syarwani, 2013; Murtilaksono dan Anwar, 2014). Pemanfaatan lahan kering untuk produksi pangan masih terbuka lebar. Luas lahan kering dan potensial untuk pertanian di Indonesia dilaporkan sebesar 12,9 juta hektar (Idjudin dan Marwanto, 2008).

Keracunan alumunium menjadi pembatas pertumbuhan tanaman. Tanaman tercekam alumunium akan berdampak pada perkembangan akar pendek, rapuh, dan menebal yang disebabkan oleh adanya penghambatan perpanjangan dan pembelahan sel (Marschner, 1992). Kondisi ini mengakibatkan terhambatnya penyerapan nutrisi oleh tanaman. Cara yang umum untuk mengurangi keracunan alumunium adalah aplikasi bahan organik tinggi. Bahan organik yang mudah larut dan mengandung asam-asam fulvik dapat mengurangi keracunan alumunium. Penggunaan bahan organik dapat membantu jika cekaman alumunium hanya terjadi pada lapisan olah atau topsoil. Namun bila cekaman alumunium terjadi hingga lapisan subsoil, maka penggunaan varietas toleran dan adaptif sangat dianjurkan.

Tidak hanya pola tanam ekstensifikasi yang harus dilakukan untuk meningkatkan produktivitas padi namun, penyadartahuan tentang teknik budidaya yang tepat dan ramah lingkungan juga harus ditingkatkan. Pendampingan ke petani untuk penerapan paket inovasi pertanian perlu terus dilakukan terutama di kawasan lahan sub optimal. Pendekatan dalam optimalisasi lahan kering bisa dilakukan antara lain dengan perbaikan varietas dan teknologi budidaya seperti penggunaan pupuk berimbang, penggunaan bahan pembenah tanah (pupuk kandang, kapur, zeolit) dan sistem tanam jajar legowo (Hafif, 2016).

Agar hasil perakitan tanaman padi tersebut tepat sasaran, dan bermanfaat bagi pengguna, maka tidaklah salah jika pada saat melakukan seleksi keragaan tanaman pada setiap lokasi melibatkan petani sebagai calon pengguna akhir. Jejak pendapat dan penilaian mereka menjadi dasar pengembangan galur/ varietas tertentu di suatu daerah tertentu. Beberapa hasil kegiatan pemuliaan partisipasi yang melibatkan calon pengguna (petani/masyarakat) telah diakukan pada beberapa jenis tanaman antara lain: jagung (Witcombe et al, 2003), ubi jalar (Kiiza et al.2012) dan padi (Hairmansis et al. 2015).

Kabupaten Tabalong dipilih sebagai lokus penelitian karena memiliki karena memiliki lahan ladang atau huma sekitar 7.969 hektar (BPS, 2019). Lahan seluas ini sangat potensial untuk pengembangan padi gogo. Selain itu, selama ini petani hanya dapat menanam padi sebanyak satu kali dalam setahun karena penggunaan varietas lokal yang berumur panjang (lebih dari 6 bulan) dengan produksi rendah sekitar 2 ton/ha. Selain itu, Tabalong juga memiliki perkebunan karet seluas 69.338 ha. Areal merupakan salah satu potensi yang lain untuk pengembangan padi gogo. Pada saat tanaman karet sudah tidak berproduksi dengan baik, pohon karet akan ditebang dan diganti bibit karet baru. Areal bekas tebangan karet dijadikan ladang bertaman padi, sekaligus memanfaatkan lahan selama masa tunggu tanaman karet produktif. Saat ini kontribusi sektor kehutanan dalam ketersediaan pangan nasional 
mencapai 3.4 juta ton/tahun untuk komoditas padi, jagung, kedelai dan umbi-umbian (Mayrowani dan Ashari, 2011). Alih fungsi hutan ke non hutan (deforestasi) dapat mengubah bentuk ekosistem tertutup menjadi terbuka, yang menyebabkan siklus unsur hara dapat hilang dari ekosistem tersebut (Firmansyah, 2010). Penelitian bertujuan untuk mengetahui penilaian calon pengguna terhadap 15 galur harapan padi gogo yang terindikasi toleran aluminium berdasarkan keragaan fenotipik tanaman di lokasi tersebut.

\section{BAHAN DAN METODE}

Penelitian dan demplot dilakukan di Desa Bintang Ara, Kecamatan Bintang Ara, Kabupaten
Tabalong, Kalimantan Selatan. Periode percobaan pada Oktober 2018 - Februari 2019. Pengumpulan data observasi oleh petani dilakukan pada Februari 2019 saat tanaman padi gogo menjelang panen. Pengkajian menggunakan metode survey melibatkan 30 orang petani sebagiai responden di Desa tersebut. Data dikumpulkan melalui wawancara menggunakan kuisioner terstruktur. Penentuan sampel responden dilakukan secara sengaja (purposive sampling). Sebagai bahan penilaian petani, ditanam 15 galur harapan padi gogo toleran alumunium (Tabel 1) pada lahan bekas pertanaman karet. Seluruh genotipe ditanam secara tugal pada petak seluas 1 x $5 \mathrm{~m}$ dengan jarak tanam 20 × $20 \mathrm{~cm}$ tanpa rancangan percobaan.

Tabel 1. Galur harapan yang di survey sebagai bahan genetik

\begin{tabular}{cccccc}
\hline No. & Kode Galur & No. & Kode Galur & No. & Kode Galur \\
\hline 1 & G1 & 6 & G10 & 11 & G22 \\
2 & G2 & 7 & G12 & 12 & G23 \\
3 & G3 & 8 & G18 & 13 & G29 \\
4 & G4 & 9 & G19 & 14 & G31 \\
5 & G9 & 10 & G21 & 15 & G33 \\
\hline
\end{tabular}

Tabel 2. Hasil analisis kimia tanah Kabupaten Tabalong (2018)

\begin{tabular}{|c|c|c|c|c|c|c|c|}
\hline Lokasi & $\mathrm{pH}$ & $\mathrm{C}$ & $\mathrm{N}$ & $\begin{array}{l}\text { P tersedia } \\
\quad(\mathrm{ppm})\end{array}$ & $\begin{array}{l}\mathrm{K} \text { tersedia } \\
(\mathrm{me} / 100 \mathrm{~g})\end{array}$ & $\begin{array}{l}\text { Ca tersedia } \\
(\mathrm{me} / 100 \mathrm{~g})\end{array}$ & $\begin{array}{c}\text { Mg tersedia } \\
(\mathrm{me} / 100 \mathrm{~g})\end{array}$ \\
\hline Haruai & 6.32 & 4.79 & 0.41 & 223.35 & 0,2 & 0,4 & 0,19 \\
\hline Bintang Ara & 5.75 & 5.63 & 0.49 & 35.51 & 0,28 & 0,54 & 0,27 \\
\hline \multicolumn{8}{|l|}{ Kriteria penilaian* } \\
\hline Sangat rendah & & $<1$ & $<0,1$ & $<5$ & $<0,1$ & $<2$ & $<0,3$ \\
\hline Rendah & & 2-Jan & $0,1-0,2$ & 16-May & $0,1-0,3$ & $5-\mathrm{Feb}$ & $0,4-1$ \\
\hline Sedang & & $3-\mathrm{Feb}$ & $0,21-0,5$ & $17-24$ & $0,4-0,5$ & 10-Jun & $1,1-2,0$ \\
\hline Tinggi & & 5-Mar & $0,51-0,75$ & $25-40$ & $0,6-1,0$ & 20-Nov & $2,1-8,0$ \\
\hline Sangat tinggi & & $>5$ & $>0,75$ & $>40$ & $>1$ & $>20$ & $>8$ \\
\hline
\end{tabular}

*Sumber : Balai Penelitian Tanah, 2009 
Pemeliharaan tanaman dilakukan secara optimum.

Penilaian galur dilakukan berdasarkan sifat morfologi tanaman di lapangan. Data hasil pemilihan galur dihitung nilai preferensi varietas menggunakan rumus (Paris et al., 2011).

Nilai Preferensi Varietas

$$
=\frac{\text { Jumlah suara suka }- \text { Jumlah suara tidak suka }}{\text { Jumlah total suara }}
$$

\section{HASIL DAN PEMBAHASAN}

\section{a. Karakeristik Responden}

Berdasarkan data, 90\% responden adalah pria dengan rentang usia 41-50 tahun. Mata pencaharian utama mereka sebagian besar adalah petani $(96,7 \%)$ dengan masa kerja antara 31- 40 tahun (Tabel 3). Sementara terkait jenis padi di area tersebut menujukkan bahwa jenis padi yang banyak ditanam petani Bintang Ara adalah padi gogo/ ladang non hibrida (67.7\%) dan $22.7 \%$ padi hibrida serta sebagian kecil lainnya padi gogo lokal (Tabel 4).

Informasi status kepemilikan lahan menunjukkan bahwa 93,3\% petani Bintang Ara memiliki lahan sendiri yang berkisar 1-3 ha, yang diduga terkategori luas (Tabel 5). Hal ini selaras dengan komoditi utama yang dibudidayakan yaitu tanaman karet. Meskipun padi bukan tanaman utama, namun lahan sela yang digunakan cukup luas. Dengan luasan tersebut kisaran hasil panen padi per musim tanam tergolong rendah (1-5 ton). Menurut petani, rendahnya hasil panen dikarenakan kesuburan lahan rendah dan varietas yang digunakan tidak toleran kekeringan. Penggunaan varietas unggul baru dapat menekan pengaruh cekaman biotik dan abiotik, serta memberikan kontribusi besar terhadap peningkatan produksi padi nasional sebasar $56 \%$ (Syahri dan Somantri, 2016; Nurhati et al., 2008).

Tabel 6 memberikan informasi pemanfaatan

Tabel 3. Informasi responden

\begin{tabular}{llc}
\hline & Karakteris tik Identitas Res ponden & Jumlah Res ponden (\%) \\
\hline Jenis Kelamin & Pria & 90,0 \\
& Wanita & 10,0 \\
\hline Usia & $20-30$ Tahun & 13,3 \\
& $31-40$ Tahun & 23,3 \\
& $41-50$ Tahun & 40,0 \\
& $51-60$ Tahun & 16,7 \\
& $>60$ Tahun & 6,7 \\
\hline Pekerjaan & Petani & 96,7 \\
& Pedagang & 0,0 \\
& Swasta & 0,0 \\
& Ibu Rumah Tangga & 3,3 \\
\hline Umur profesi sebagai petani & $<10$ th & 23,3 \\
& $10-20$ th & 10,0 \\
& $21-30$ th & 13,3 \\
& $31-40$ th & 40,0 \\
& $>40$ th & 13,3 \\
\hline
\end{tabular}


Tabel 4. Informasi jenis tanaman padi yang diminati petani setempat

\begin{tabular}{llc}
\hline \multicolumn{2}{c}{ Jenis tanaman padi yang di minati } & Jumlah Responden (\%) \\
\hline Jenis pertanaman padi & Sawah & 0,0 \\
& Gogo & 100,0 \\
\hline Jenis varietas padi & Lokal & 6,7 \\
& Nasional: & \\
& a. Hibrida & 26,7 \\
& b. Non hibrida & 66,7 \\
\hline
\end{tabular}

Tabel 5. Informasi status kepemilikan lahan

\begin{tabular}{lcc}
\hline & Status Ke pe milikan lahan & Jumlah Responden (\%) \\
\hline Status lahan & Milik sendiri & 93,3 \\
& Sewa & 0,0 \\
& Kerjasama & 6,7 \\
\hline Luas lahan & $<500 \mathrm{~m}$ & 6,7 \\
& $500-1000 \mathrm{~m}$ & 0,0 \\
& $1000-5000 \mathrm{~m}$ & 0,0 \\
& $5000-1 \mathrm{ha}$ & 3,3 \\
& $1-3$ ha & 70,0 \\
& $>3$ ha & 20,0 \\
\hline
\end{tabular}

Tabel 6. Informasi pemanfaatan produksi padi oleh petani

\begin{tabular}{lcc}
\hline & Pemanfaatan Hasil & Jumlah Responden (\%) \\
\hline Rata-rata hasil/panen & $<5 \mathrm{kw}$ & 0,0 \\
& $5-9 \mathrm{kw}$ & 0,0 \\
& $1-5$ ton & 96,7 \\
& $6-10$ ton & 3,3 \\
\hline Penggunaan hasil panen & Dijual & 20,0 \\
& Konsumsi sendiri & 33,3 \\
& Disimpan & 13,3 \\
& Lainnya & 33,3 \\
\hline Distribusi hasil & Koperasi & 3,3 \\
& Pengumpul & 80,0 \\
& Jual sendiri & 6,7 \\
& Lainnya & 10,0 \\
\hline
\end{tabular}

hasil panen oleh petani setempat. Sebanyak $20 \%$ hasil panen dijual ke pengumpul, dan 33,3\% dikonsumsi sendiri, 13,3\% disimpan dan sisanya untuk keperluan lainnya. Petani di Bintang Ara mudah mendapat benih sumber sebagai bahan tanam. Kemudahan tersebut karena lancarnya penyaluran benih bantuan pemerintah atau pihak lainnya (Tabel 7). Pada kondisi tertentu jika harus membeli benih, harga benih di pasaran masih terjangkau.

Informasi tingkat pengembangan wawasan petani tentang pertanian diketahui bahwa sebagian besar telah mengikuti pelatihan, dengan frekuensi 1-5 kali hingga lebih dari 10 kali. Sebanyak 46,7 \% responden mengukuti pelatihan rutin dua mingguan, 
Tabel 7. Informasi ketersedian benih sumber

\begin{tabular}{llc}
\hline & Status benih sumber & Jumlah Responden (\%) \\
\hline Kemudahan memperoleh benih & Sangat mudah & 23,3 \\
& mudah & 73,3 \\
& Agak sulit & 3,3 \\
& sulit & 0,0 \\
\hline Sumber perolehan benih & membeli & 0,0 \\
& bantuan (pemerintah/lainnya) & 100,0 \\
& produksi sendiri & 0,0 \\
\hline Tingkat harga & Mahal & 0,0 \\
& Sedang & 20,0 \\
& Murah & 80,0 \\
\hline Kebutuhan per musim tanam & $<10 \mathrm{Kg}$ & 0,0 \\
& $10-15 \mathrm{Kg}$ & 0,0 \\
& $15-20 \mathrm{Kg}$ & 0,0 \\
& $20-25 \mathrm{Kg}$ & 50,0 \\
& $>25 \mathrm{Kg}$ & 50,0 \\
\hline
\end{tabular}

Tabel 8. Informasi tingkat pengembangan wawasan petani tentang pertanian

\begin{tabular}{llc}
\hline & Pengembangan wawas an petani & Jumlah Res ponden (\%) \\
\hline Keikutsertaan pelatihan & Pernah & 33,3 \\
& kadang-kadang & 43,3 \\
& sering & 16,7 \\
& tidak pernah & 6,7 \\
\hline Durasi keikutsertaan pelatihan & $1-5$ kali & 36,7 \\
& $5-10$ kali & 23,3 \\
& $>10$ kali & 40,0 \\
\hline \multirow{3}{*}{ Tingkat rutinitas keikutsertaan pelatihan } & 1 minggu sekali & 3,3 \\
& 2 minggu sekali & 46,7 \\
& 1 bulan sekali & 16,7 \\
& $>1$ bulan sekali & 33,3 \\
\hline Sumber informasi pertanian & Media elektronik & 6,7 \\
& Media massa & 0,0 \\
& Penyuluh pertanian & 93,3 \\
\hline
\end{tabular}

$16,7 \%$ satu kali dalam sebulan, dan 33,3\% lebih dari sebulan sekali. Berdasarkan informasi 93,3\% menyatakan bahwa tingginya tingkat pertemuan petani salah satunya karena peran aktif penyuluh pertanian lapangan. Penyuluh pertanian memiliki posisi yang strategis dalam pengembangan kelompok tani dan peningkatan pendapatan petani melalui penerapan teknologi (Hasan et al., 2016; Saputri et al., 2016; Mulyani et al., 2017)
Studi serupa untuk mengetahui preferensi petani terhadap varietas padi baru telah dilakukan antara lain di kabupaten Bogor, Kabupaten Bangka Selatan, Pangandaran dan Cilacap. Pada daerah tersebut responden umumnya petani dengan jumlah antara 15-64 orang. Metode yang digunakan adalah wawancara dengan kuisioner terstruktur. Padi yang dipilih selanjutnya dapat dikembangkan di daerah tersebut karena sesuai dengan kondisi wilayah dan 
keinginan petani sebagai pengguna (Haryati dan Sukmaya, 2015; Fachrista et al, 2012; Prayoga et al., 2018).

\section{b. Karakteristik Galur Terpilih}

Studi preferensi untuk tanaman padi di beberapa dearah menjukkan bahwa karakteristik padi yang disukai oleh responden adalah produktivitas tinggi, tahan cekaman biotik dan abiotik serta tekstur nasi yang enak (Haryati dan Sukmaya, 2015; Fachrista et al, 2012; Prayoga et al., 2018). Informasi tentang minat responden terhadap fenotipe tanaman padi di lapangan tertuang pada Tabel 9. Responden petani Bintang Ara secara umum menyukai tanaman padi dengan karakter: tinggi tanaman sedang, batang ungu, daun hijau tua, daun panjang, kemiringan sudut daun bendera sedang, jumlah anakan banyak, dan umur tanaman sedang. Sementara untuk karakter malai dan bulir gabah responden menyukai panjang malai sedang dengan jumlah 5-10 malai per rumpun. Pada umumnya responden petani menyukai tanaman padi dengan tingkat kerontokan gabah yang berkisar antara agak mudah - sedang, bentuk bulir ramping, warna bulir kuning emas, warna kulit ari putih, dan aroma beras tanak sedikit wangi (Tabel 10).

Informasi status organisme pengganggu tanaman yang sering menyerang pertanaman padi petani Bintang Ara terangkum dalam Tabel 11. Data hama penyakit yang terekam merupakan organisme yang paling sering ditemukan oleh petani di lapangan

Tabel 9. Informasi minat petani terhadap penampilan/karakter tanaman padi secara umum

\begin{tabular}{llc}
\hline & Minat terhadap penampilan tanaman padi & Jumlah Responden (\%) \\
\hline Tinggi tanaman & Pendek & 10,0 \\
& Sedang & 90,0 \\
& Tinggi & 0,0 \\
\hline Warna Batang & Hijau muda & 20,0 \\
& ungu & 80,0 \\
\hline Warna daun & Hijau muda & 0,0 \\
& Hijau & 3,3 \\
& Hijau tua & 96,7 \\
& ungu diujung daun & 0,0 \\
& ungu dipinggir daun & 0,0 \\
\hline Panjang daun & Pendek & 0,0 \\
& Sedang & 16,7 \\
& Panjang & 83,3 \\
\hline Posisi daun bendera & Tegak & 40,0 \\
& Sedang & 60,0 \\
& Mendatar & 0,0 \\
& Terkulai & 0,0 \\
\hline Jumlah anakan & Sedikit & 3,3 \\
& Sedang & 30,0 \\
& Banyak & 63,3 \\
& Sangat banyak & 3,3 \\
\hline Umur tanaman & Genjah & 16,7 \\
& Sedang & 83,3 \\
& Dalam & 0,0 \\
\hline
\end{tabular}


Tabel 10. Informasi minat petani terhadap karakter malai dan gabah padi

\begin{tabular}{llc}
\hline & Minat petani terhadap karakter malai dan biji & Jumlah Responden (\%) \\
\hline Jumlah malai & $<5$ malai/rumpun & 6,7 \\
& $5-10$ malai/rumpun & 80,0 \\
& $>10$ malai/rumpun & 13,3 \\
\hline Panjang malai & Pendek & 16,7 \\
& Sedang & 83,3 \\
& Panjang & 0,0 \\
\hline Tingkat kemudahan kerontokan biji & Mudah & 6,7 \\
& Agak Mudah & 46,7 \\
& Sedang & 46,7 \\
& Sulit & 0,0 \\
\hline Bentuk bulir & Ramping & 70,0 \\
& Sedang & 23,3 \\
& Lonjong & 6,7 \\
& Bulat & 0,0 \\
\hline Warna Bulir & Kuning jerami & 6,7 \\
& Kuning emas & 83,3 \\
& Kuning bercak & 10,0 \\
& Kemerahan-ungu & 0,0 \\
\hline Warna kulit ari & Putih & 90,0 \\
& coklat muda & 3,3 \\
& Bercak coklat & 0,0 \\
& Coklat & 0,0 \\
& Merah Ungu & 6,7 \\
\hline Aroma beras & Tidak wangi & 0,0 \\
& Sedikit wangi & 90,0 \\
& wangi & 10,0 \\
\hline
\end{tabular}

selain selama pertanaman berlangsung. Selama pertanaman padi, terjadi serangan organisme pengganggu tanaman seperti walang sangit, penggerek batang, hama putih palsu, penggulung batang, dan belalang. Penyakit yang muncul antara lain busuk batang, bercak daun, dan blas. Pencegahan dilakukan dengan pemasangan perangkap dan light trap. Pengendalian hama dan penyakit dilakukan dengan aplikasi biopestisida dan kimia sesuai dosis anjuran. Aplikasi dan pengendalian yang tepat menjadikan produksi tetap terjaga. Pengendalian hama dan penyakit tanaman dilakukan jika populasi hama atau intensitas kerusakan akibat penyakit telah menunjukkan akan berimbas pada terjadinya kerugian dalam usaha pertanian atau ambang batas ekonomi (Manueke et al., 2017)

Hasil penelusuran terhadap hama penyakit yang telah dilakukan, hampir seluruh jenis penyakit utama di tanaman padi pernah menyerang pertanaman padi Bintang Ara. Menurut informasi petani setempat, penyakit yang paling sering muncul adalah hawar daun bakteri/kresek (96,7\%) dan busuk batang (83,3\%). Sedangkan penyakit blas yang merupakan penyakit utama pada padi gogo lebih sedikit muncul berdasarkan pengalaman $33,3 \%$ responden. Berdasarkan keterangan petani,jenis hama yang menyerang tanaman padi beragam, kecuali keong emas, karena hanya menyerang padi sawah. Memperhatikan data informasi 
Tabel 11. Informasi status organisme pengganggu tanaman yang sering menyerang tanaman padi setempat

\begin{tabular}{llc}
\hline & Status Organis me Pengganggu Tanaman & Jumlah Res ponden (\%) \\
\hline Penyakit & Blas & 33,3 \\
& Kresek & 96,7 \\
& Tungro & 3,3 \\
& Bercak daun & 33,3 \\
& Busuk batang & 83,3 \\
\hline Hama & Burung & 96,7 \\
& Belalang & 83,3 \\
& Walang sangit & 100,0 \\
& Penggerek Batang & 86,7 \\
& Hama putih palsu & 90,0 \\
& Penggulung daun & 80,0 \\
& Wereng & 86,7 \\
\end{tabular}

Tabel 12. Rangkuman hasil penjajakan minat petani Bintang Ara-Kabupaten Tabalong terhadap tanaman padi yang diinginkan.

\begin{tabular}{|c|c|}
\hline Informasi & Keterangan \\
\hline \multicolumn{2}{|l|}{ Status tanaman padi yang ditanam } \\
\hline Jenis padi & Gogo \\
\hline Status jenis padi & Non hibrida \\
\hline \multicolumn{2}{|l|}{ Status Kepemilikan lahan } \\
\hline Status lahan & Milik sendiri \\
\hline Luas lahan & $1-3 \mathrm{ha}$ \\
\hline \multicolumn{2}{|l|}{ Pemanfaatan Hasil } \\
\hline Rata-rata hasil/panen & $1-5$ ton \\
\hline Penggunaan hasil panen & konsumsi \\
\hline Lokasi jual & Pengumpul \\
\hline \multicolumn{2}{|l|}{ Status benih sumber } \\
\hline Kemudahan memperoleh benih & mudah \\
\hline Sumber perolehan benih & bantuan pemerintah/lainnya \\
\hline Tingkat harga & Murah \\
\hline Kebutuhan per musim tanam & 20-25 lebih /ha \\
\hline \multicolumn{2}{|l|}{ Pengembangan wawas an petani } \\
\hline Keikuts ertaan pelatihan & kadang-kadang \\
\hline Durasi keikuts ertaan pelatihan & $>10$ kali \\
\hline Tingkat rutinitas keikutsertaan pelatihan & 2 minggu sekali \\
\hline Sumber informasi pertanian & Penyuluh pertanian \\
\hline \multicolumn{2}{|c|}{ Minat terhadap penampilan keragaan tanaman padi } \\
\hline Tinggi tanaman & Sedang \\
\hline Warna Batang & ungu \\
\hline Warna daun & Hijau tua \\
\hline Panjang daun & Panjang \\
\hline Posisi daun bendera & Sedang \\
\hline Jumlah anakan & Banyak \\
\hline Umur tanaman & Sedang \\
\hline \multicolumn{2}{|c|}{ Minat petani terhadap karakter malai tanaman padi } \\
\hline Jumlah malai & 5-10 malai/rumpun \\
\hline Panjang malai & Sedang \\
\hline \multicolumn{2}{|l|}{ Minat petani terhadap karakter biji } \\
\hline Tingkat kemudahan kerontokan biji & agak mudah-sedang \\
\hline Bentuk bulir & Ramping \\
\hline Warna Bulir & Kuning emas \\
\hline Warna kulit ari & Putih \\
\hline Aroma beras & Sedikit wangi \\
\hline
\end{tabular}


Tabel 13. Preferensi petani responden terhadap galur-galur harapan padi gogo terindikasi toleran alumunium

\begin{tabular}{ccccc}
\hline \multirow{2}{*}{ No Galur } & \multicolumn{2}{c}{ Jumlah Suara } & \multirow{2}{*}{ Jumlah Responden } & \multirow{2}{*}{ Nilai Preferensi } \\
\cline { 2 - 3 } & Suka & Tidak Suka & 30 & $\mathbf{0 , 6 7}$ \\
2 & 25 & 5 & 30 & $\mathbf{0 , 5 3}$ \\
3 & 23 & 7 & 30 & $-0,53$ \\
4 & 7 & 23 & 30 & $\mathbf{0 , 5 3}$ \\
9 & 23 & 7 & 30 & $-1,00$ \\
10 & 0 & 30 & 30 & $-0,87$ \\
12 & 2 & 28 & 30 & 0,27 \\
18 & 19 & 11 & 30 & $-1,00$ \\
19 & 0 & 30 & 30 & $-1,00$ \\
21 & 0 & 30 & 30 & 0,27 \\
22 & 19 & 11 & 30 & $\mathbf{0 , 6 0}$ \\
23 & 24 & 6 & 30 & $\mathbf{0 , 6 0}$ \\
29 & 24 & 6 & 30 & $-1,00$ \\
31 & 0 & 30 & 30 & $-0,80$ \\
33 & 3 & 27 & 30 & $-0,53$ \\
\hline
\end{tabular}

petani Bintang Ara, lebih dari $80 \%$ responden menggambarkan tingginya serangan hama yang menyerang tanaman padi. Hal ini merupakan salah satu faktor penyebab kehilangan hasil bahkan gagal panen yang dialami petani setempat.

Serangan hama dan penyakit pada umumnya berhubungan dengan kondisi di daerah tersebut. Rendahnya penyakit blas yang merupakan penyakit utama padi gogo kemungkinan karena daerah tersebut bukan termasuk endemik penyakit blas. Lokasi lahan di Bintang Ara merupakan daerah bekas perkebunan karet. Penyakit yang banyak menyerang pada tanaman karet meliputi penyakit jamur pada akar yang disebabkan oleh $R$ lignosus, penyakit daun yang disebabkan oleh Phytopthora sp, Colletotrichum dan penyakit batang yang disebabkan oleh Fusarium solani (Defitri, 2014). Diduga hal ini juga berpengaruh terhadap pertanaman padi yang ditanam di Bintang Ara.
Secara umum, petani Bintang Ara merupakan petani yang terbina dengan baik. Penerapan sistem budidaya padi sudah dilakukan dengan baik. Peran penyuluh pertanian lapangan sangat membantu dalam pendampingan penerapan sistem budidaya. Keterlibatan pemerintah dalam penyediaan benih dan pupuk juga diterima petani. Luas kepemilikan lahan rata-rata 1-3 ha per orang merupakan potensi besar bagi pengembangan padi di Kabupaten Tabalong mendukung ketahanan pangan stempat.

Berdasarkan nilai preferensi petani terhadap penampilan tanaman galur harapan padi gogo LIPI tampak bahwa dari 15 galur yang diuji, secara berurut dari yang paling disuka responden memilih galur nomor 1, 22, 23, 2, dan 4. Penilaian petani dilakukan pada saat padi memasuki umur panen dengan mengamati secara visual penampakan tanaman padi di lapangan (Tabel 13). 


\section{KESIMPULAN}

Petani Bintang Ara merupakan petani terbina dengan akses informasi tentang pertanian yang diperoleh dari peran aktif penyuluh lapang pertanian setempat. Lahan yang tersedia sebagian besar merupakan lahan bekas pertanaman karet. Permasalahan yang dihadapi oleh petani antara lain tingkat kesuburan tanah rendah dan tingginya serangan hama penyakit tanaman, sehingga produksi padi gogo rendah setiap musimnya. Pengembangan varietas baru perlu memperhatikan preferensi petani Karakteristik tanaman yang dipilih oleh petani setempat adalah tinggi tanaman sedang, lebar sudut daun bendera sedang, jumlah anakan banyak, umur tanaman sedang, jumlah malai banyak, panjang malai sedang, tingkat kerontokan padi mudah, bentuk bulir ramping, warna bulir kuning emas, dan aroma beras wangi. Hasil penjajakan preferensi petani terhadap galur harapan padi gogo toleran aluminium, terpilih 5 nomor galur terbaik (secara berurutan): G1, G22, G23, G2, dan G4 sehingga galurgalur tersebut mempunyai potensi untuk dikembangkan di daerah Bintang Ara, Tabalong.

\section{UCAPAN TERIMAKASIH}

Kegiatan ini terselenggara melalui Progran DIPA Prioritas Nasional Pangan 2018 LIPI. Terima kasih disampaikan kepada Bupati Kabupaten Tabalong, Kepala Dinas Pertanian Kabupaten Tabalong, Kepala Balai Penyuluhan Pertanian Bintang Ara, dan para kelompok tani Bintang Ara Kabupaten Tabalong atas kerjasama selama kegiatan penelitian lapangan ini berlangsung.

\section{DAFTAR PUSTAKA}

BPS. 2019. Kabupaten Tabalong dalam angka 2019. Badan Pusat Statistik Kabupaten Tabalong.

Balai Penelitian Tanah. 2009. Petunjuk teknis edisi 2: analisis kimia tanah, tanaman, air dan pupuk. Balai Besar Litbang Sumber Daya Lahan Pertanian. Kementerian Pertanian.

Defitri Y. 2014. Identifikasi jamur pathogen penyebab penyakit tanaman karet (Havea brasiliensis) di Sukajaya Kecamatan Bayung Lincir Kabupaten Musi Banyuasin Sumatera Selatan. Jurnal Ilmiah Universitas Batanghari Jambi. 14(4): 98-102

Fachrista IA, Issukindarsyah, D Rusmawan, HA Dewi. 2012. Preferensi petani di Kabupaten Bangka Selatan terhadap beberapa varietas unggul padi sawah. Seminar Nasional Kedaulatan Pangan dan Energi. Fakultas Pertanian Universitas Trunojoyo, Madura.

Firmansyah MA. 2010. Respon tanaman terhadap aluminium. Agripura. 6(2): 807-818

HafifB. 2016. Optimasi potensi lahan kering untuk pencapaian target peningkatan produksi padi satu juta ton di propinsi Lampung. Jurnal Litbang Pertanian. 35(2): 81-88

Hairmansis A., Supartopo, Suwarno. 2015. Seleksi varietas partisipatif terhadap galur-galur elit padi gogo di lahan petani. Ilmu Pertanian. 18(2):61-68

Haryati Y, Sukmaya. 2015. Preferensi petani terhadap varietas unggul di Kabupaten Bogor. Agros. 17(1); $145-152$ 
Hasan, S., W. Tilaar, L. T. Karamoy. 2016. Pengaruh Penyuluhan Pertanian dalam Aspek Lingkungan, Ekonomi dan Teknologi pada Petani Padi Sawah di Kecamatan Modayag. Agri-Sosio Ekonomi Unsrat. 12(3A): 165 178

Idjudin, A.A., S. Marwanto. 2008. Reformasi pengelolaan lahan kering untuk mendukung swasembada pangan. Jurnal sumberdaya lahan. 2(2): 115-125

Iqbal, M.T. 2012. Acid tolerance mechanisms in soil grown plants. Malay. J. Soil Sci. 16: 1-21.

Kiiza B., LG. Kisembo, ROM Mwanga. 2012. Participatory plant breeding and selection impact on adoption sweetpotato varieties in Uganda. Journal of Agricultural Science and Technology. 673-681

Manueke, J., B. H. Assa, A. E. Pelealu. 2017. Rekomendasi teknologi pengendalian hama secara terpadu (pht) hama tanaman padi sawah (oryza sativa) di desa makalonsow kecamatan tondano timur kabupaten minahasa. Jurnal LPPM Bidang Sains dan Teknologi. 4(1): 23-34

Marschner, H. 1992. Mechanisms of adaptation of plants on acid soils. Plant and Soil. 134: 120

Matsumoto S, H. Shimada, T. sasaoka, I. Miyajima, GJ. Kusuma, RS Gautama. 2017. Effects of Acid Soils on Plant Growth and Successful Revegetation in the Case of Mine Site. Chapter 2.ppP 10-26. http://dx.doi.org/10.5772/ intechopen.70928
Mayrowani H, Ashari. 2011. Pengembangan agroforestry untuk mendukung ketahanan pangan dan pemberdayaan petani sekitar hutan. Forum Penelitian Agro Ekonomi. 29(2): 8398

Mulyani A., M. Sarwani. 2013. Karakteristik dan Potensi Lahan Sub Optimal untuk Pengembangan Pertanian di Indonesia. Jurnal Sumberdaya Lahan. 7 (1): 47-55

Mulyani, S. I., Dewi Elviana CCW, Budi Rosen Nover S. 2017. Peranan Penyuluh Pertanian dalam Peningkatan Pendapatan Petani Komoditas Padi di Kecamatan Tanjungselor Kabupaten Bulungan Kalimantan Utara. Jurnal Agrifor. 16(1): 103-108

Murtilaksono K., S. Anwar. 2014. Potensi, Kendala, dan Strategi Pemanfaatan Lahan Kering dan Kering Masam untuk Pertanian (Padi, Jagung, Kedele), Peternakan, dan Perkebunan dengan Menggunakan Teknologi Tepat Guna dan Spesifik Lokasi. Prosiding Seminar Nasional Lahan Suboptimal 2014. Hal 17-28

Nurhati, I.,S. Ramdhaniati, N. Zuraida. 2008. Peranan dan Dominasi Varietas Unggul Baru dalam Peningkatan Produksi Padi di Jawa Barat. Buletin Plasma Nutfah. 14(1):8-13

Subagyo, H., N. Suharta, AB. Siswanto. 2000. Tanahtanah Pertanian di Indonesia. Halaman 21-66 pada Buku Sumberdaya Lahan Indonesia dan Pengelolaannya. Pusat Penelitian Tanah dan Agroklimat, Bogor.

Saputri, R.D., S. Anantanyu, A. Wijianto. 2016. Peran Penyuluh Pertanian Lapangan dengan Tingkat Perkembangan Kelompok Tani di Kabupaten Sukoharjo. Agrista. 4(3): 341 - 352 